\title{
THE INFLUENCE OF THE MORPHOLOGY OF IRON POWDER PARTICLES ON THEIR COMPACTION IN AN AUTOMATIC DIE
}

\author{
VPLIV MORFOLOGIJE DELCEV ŽELEZOVEGA PRAHU NA \\ NJEGOVO SPOSOBNOST ZA AVTOMATSKO ENOOSNO \\ STISKANJE
}

\author{
Borivoj Šuštaršičํ, Matjaž Godec ${ }^{1}$, Črtomir Donik ${ }^{1}$, Irena Paulin ${ }^{1}$, \\ Srečko Glodež ${ }^{2}$, Marko Šori ${ }^{2}$, Milan Ratej ${ }^{3}$, Nada Javornik ${ }^{3}$ \\ ${ }^{1}$ Institute of Metals and Technology, Lepi pot 11, 1000 Ljubljana, Slovenia \\ ${ }^{2}$ University of Maribor, FNM, Koroška cesta 160, 2000 Maribor, Slovenia \\ ${ }^{3}$ UNIOR, Forging Industry, Kovaška cesta 10, 3214 Zreče, Slovenia \\ borivoj.sustarsic@imt.si
}

Prejem rokopisa - received: 2014-10-24; sprejem za objavo - accepted for publication: 2014-12-16

doi:10.17222/mit.2014.273 \begin{abstract}
Fe- and steel-based powder metallurgy (P/M) products, such as steel gears, spurs, locking mechanisms, porous filters, sliding
bearings and bushes, as well as other machine parts and structural elements, are mainly produced with the so-called conventional sintering technology. It is the most efficient technology for the mass production of small, complex, functional and structural parts. Therefore, it is the most convenient and popular among all of the P/M technologies. The most important end-user of sintered parts is the automotive industry. However, small, complex, sintered parts can also be frequently used in the furniture and household industries, precise mechanics, articles for recreation and sports. A fine, iron-based powder mixture or prealloyed powder is first automatically uniaxial-die compacted (ADC) into the final shape of the product with a mechanical or hydraulic press and then sintered in a protective atmosphere at approximately $1100{ }^{\circ} \mathrm{C}$. The metal powder mixture must have the appropriate engineering properties given by the chemistry and particle morphology, enabling a fast and reliable die-compaction process. The most important are a high tap density, a good powder flowability and a low compressibility. All this gives the green compacts an appropriate final shape with a smooth surface, a relatively high and uniform green density, as well as a green strength without internal flaws and cracks. In the case of very small two-or-more-heights products, for example, spur gears with a low module, it is very difficult to obtain a uniform green density at acceptable compaction pressures. Often small cracks are formed at height crossings and big differences in the green density appear in smaller or thinner regions. In the frame of our investigation we analysed the influence of the selected prealloyed commercial iron powder's morphology and its technological properties on automatic die compaction, as well as the sintering process in the case of small two-level sintered gear dimensions of $5 / 40-7 / 10 \times 7 \mathrm{~mm}$ with module $m=0.5$. The original iron powder was sieved and the finest powder particle fraction $(<45$ $\mu \mathrm{m})$ was compared with the original powder mixture considering ADC and sintering process. It was found that the selection of the finer powder mixture could not contribute to the improvement in the overall ADC process, as well as a better green compact. In the present paper the results of our investigations are presented and the reasons why a finer powder mixture cannot contribute much to an improvement of the conventional sintering process.
\end{abstract}

Keywords: Fe-based alloy powders, morphology and microstructure of particles, influence on automatic die compaction, sintering

Jekleni izdelki, izdelani po P/M-postopkih, kot so npr. zobniki, mehanizmi za zaklepanje, porozni filtri, drsni ležaji in puše, kakor tudi drugi strojni elementi ali strukturni deli, se v glavnem izdelujejo po konvencionalni tehnologiji sintranja. To je najbolj učinkovita in zato najpopularnejša tehnologija za masovno proizvodnjo majhnih kompliciranih funkcionalnih in strukturnih izdelkov. Avtomobilska industrija je najbolj pomemben končni uporabnik sintranih delov, vendar se le-ti pogosto uporabljajo tudi v pohištveni industriji, beli tehniki, precizni mehaniki, v izdelkih za šport in rekreacijo itd. Fina prašna mešanica na osnovi Fe ali predlegiranih jeklenih delcev se najprej avtomatsko enoosno stiska v končno obliko na mehanskih al hidravličnih stiskalnicah in nato sintra $\mathrm{v}$ zaščitni atmosferi pri pribl. $1100{ }^{\circ} \mathrm{C}$. Kovinska prašna mešanica mora imeti primerne tehnološke lastnosti, ki omogočajo hiter in zanesljiv proces zgoščevanja v surovce želene oblike in velikosti. Te so definirane s fizikalno-kemijskimi lastnostmi in predvsem morfologijo (obliko in velikostjo) delcev. Najbolj pomembne so visoka nasipna gostota, dobra tekočnost in nizka stisljivost prašne mešanice. Vse to daje surovemu izdelku želeno končno obliko z gladko površino, relativno visoko in enakomerno zeleno gostoto in trdnostjo brez lokalnih napak in razpok. Pri zelo majhnih dvo- ali večvišinskih izdelkih, kot so npr. dvojni zobniki z majhnim zobniškim modulom, je zelo težko dobiti surovce (zelence) brez napak in $\mathrm{z}$ enakomerno gostoto pri sprejemljivih tlakih stiskanja. Pogosto na surovcih nastajajo razpoke na prehodu iz tanjšega $v$ debelejši del zobnika zaradi velikih razlik v zeleni gostoti. V okviru naših raziskav smo analizirali vpliv morfologije izbranega predlegiranega komercialnega Fe-prahu in njegovih tehnoloških lastnosti na razmere pri avtomatskem enoosnem stiskanju in sintranju majhnega dvovišinskega sintranega zobnika dimenzij 5/40-7/10 $\times 7 \mathrm{~mm} \mathrm{z}$ modulom $m=0,5$. Originalni Fe-prah smo presejali in najfinejšo frakcijo prahu $(<45 \mu \mathrm{m})$ uporabili za stiskanje in sintranje ter jo primerjali z originalno prašno mešanico. Ugotovili smo, da finejši prah ne prispeva $\mathrm{k}$ izboljšanju postopka avtomatskega enoosnega stiskanja oz. $\mathrm{k}$ boljšim surovcem iz več razlogov. V tem prispevku predstavljamo rezultate naših raziskav in razloge, zakaj izbira finejše prašne mešanice ne prispeva celovito k izboljšanju konvencionalnega sintrnega postopka.

Ključne besede: legirani prahovi na osnovi železa, vpliv morfologije in mikrostrukture na avtomatsko enoosno stiskanje, sintranje 


\section{INTRODUCTION}

The conventional sintering technology is the most popular among the all $\mathrm{P} / \mathrm{M}$ technologies. It enables the large-scale production of small complex parts (Figure 1) with the lowest raw-material and energy consumption. ${ }^{1-3}$ This technology is used in the Unior forging industry, Sinter workshop, Zreče, Slovenia, mainly for the production of sintered steel parts for the automotive industry. ${ }^{4}$

Sinter technology consists of three main production phases: powder manufacture and the preparation of the mixture, automatic (uniaxial cold) die compaction (ADC) and sintering (Figure 2). The improvement of the dimensional tolerances and the mechanical properties can be obtained with te additional post-sintering operations, i.e., sizing, surface and heat treatment and machining.

Some geometrical limitations exist in the phase of product design and later in the phase of tool manufacture when considering uniaxial automatic die compaction. These limitations have their origin in the nature of uniaxial ADC. Namely, the forces (pressures) of compaction are not uniformly transferred over the height and cross-section of the formed green compact because of

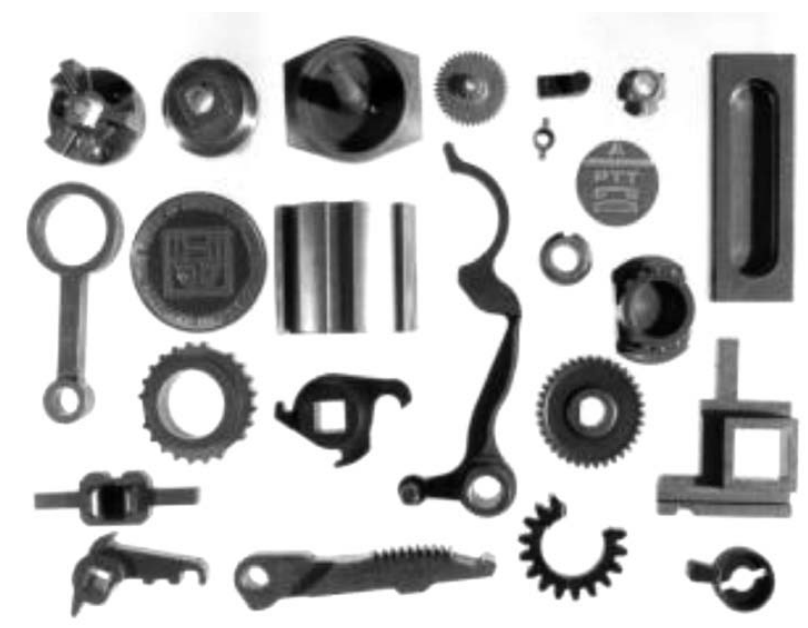

Figure 1: Some typical sintered steel parts Slika 1: Nekaj tipičnih oblik sintranih jeklenih izdelkov
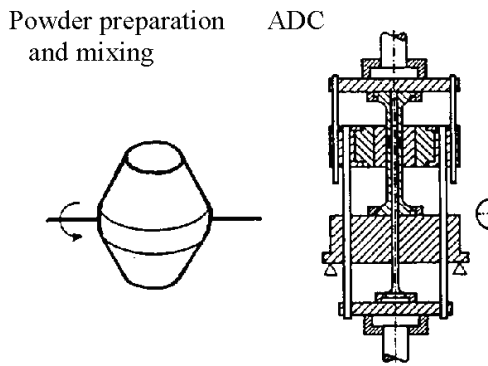

sintering
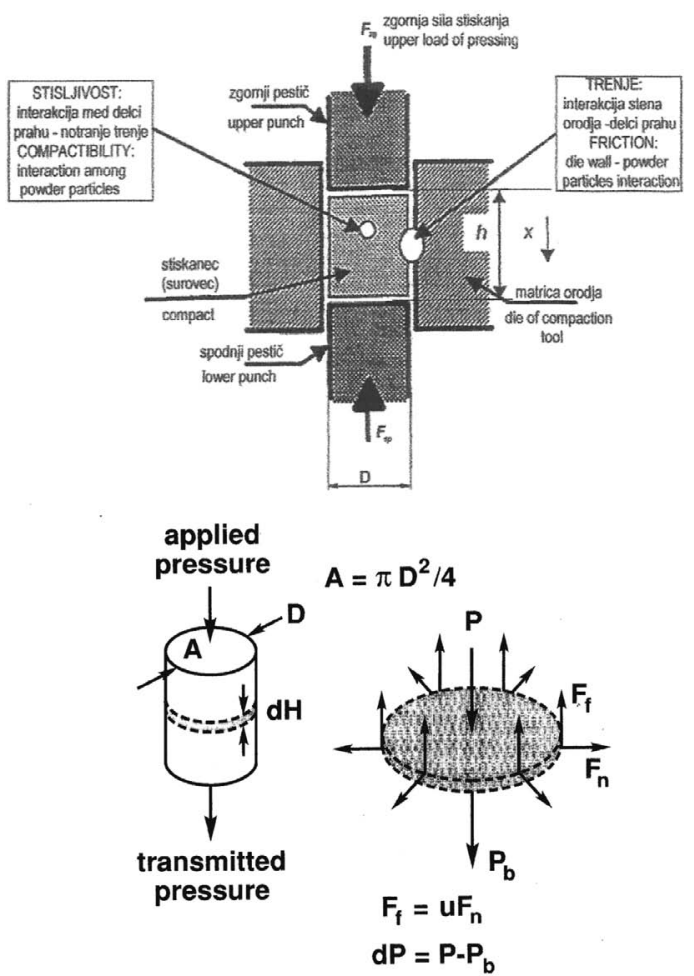

Figure 3: Schematic presentation and analysis of the uniaxial cold die compaction of metal powder in a cylindrical die $^{6}$

Slika 3: Shematični prikaz in analiza hladnega enoosnega stiskanja prahu $\mathrm{v}$ cilindričnem orodju ${ }^{6}$

the internal friction among the powder particles and the friction on the die walls (Figure 3). This has already been shown by the classic analysis ${ }^{1}$ introducing an equation where one can see that the transferred compaction force depends not only on the internal friction and the die-wall friction, but also on the ratio between the height and the diameter of the green compact $(h / D)$ :

$$
F_{x}=F_{0} \cdot e^{-4 \mu z x / D}
$$

In Equation (1) $F_{x}$ is the resulting force at a distance $x$ from the upper punch, $F_{0}$ is the acting (compaction) force on the upper punch, $\mu$ is the die-wall friction coefficient and the factor $z$ describes the ratio between 

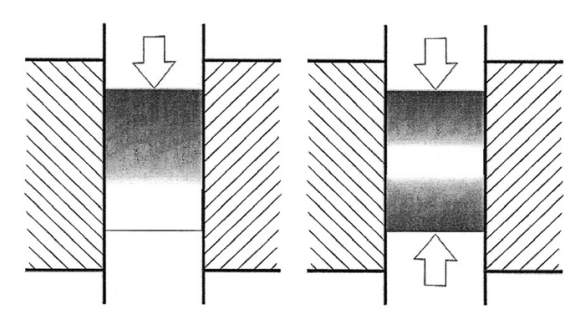

(a)

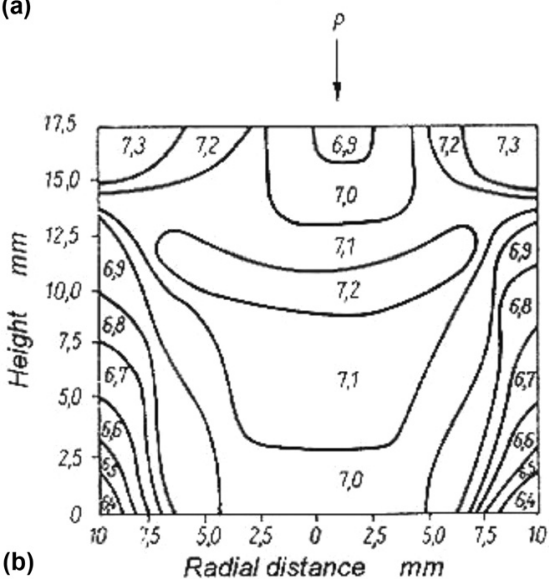

Figure 4: a) Schematic and b) practical presentation of the green-density distribution in a cylindrical specimen after the uniaxial cold compaction of steel powder 5

Slika 4: a) Shematični in b) praktični prikaz porazdelitve zelene gostote v cilindričnem surovcu po enoosnem stiskanju jeklenega prahu v orodju ${ }^{5}$

the normal and the powder-transferred radial stresses, which depends on the internal friction among the powder particles.

From Equation (1) we can calculate the transferred force at any distance $x$ in the formed green powder compact, as well as the lowest transferred force on the

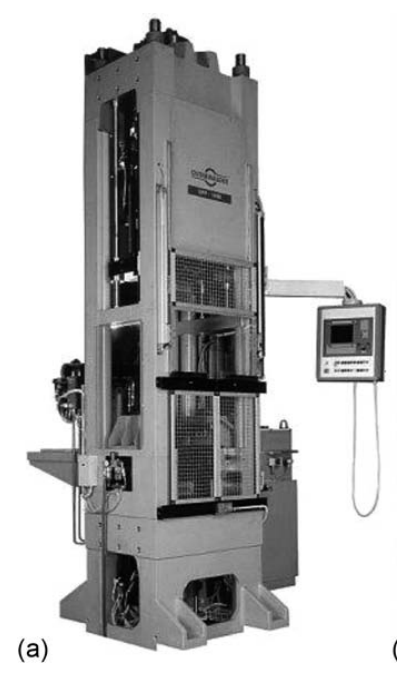

(b)

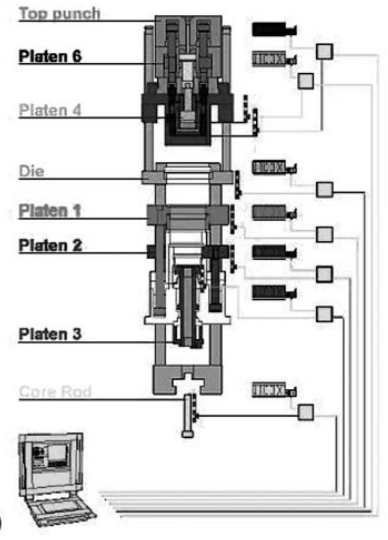

Figure 5: a) Modern hydraulic computer-controlled press for the automatic die compaction of steel powders and b) a schematic presentation of a multi-platen adapter system for the fixation of the tool into the press $^{5}$

Slika 5: a) Moderna hidravlična računalniško vodena stiskalnica za avtomatsko enoosno stiskanje jeklenih surovcev in b) shematični prikaz adapterja $\mathrm{z}$ večploščnim sistemom vpetja orodja $\mathrm{v}$ stiskalnico ${ }^{5}$ bottom punch (at $x=h$ ) if the die and powder characteristics $\mu$ and $z$ are known. The higher is the ratio $h / D$, the larger are the local differences in the green density and the formed green compact has an unequal green density over its volume (Figure 4). The higher is the compaction pressure, the higher is the local and overall (average) green density of the compact.

The green density distribution can be mitigated if the compaction force acts from both sides (top and bottom) when forming the green part. Therefore, modern tools for ADC consist of a large number of parts; their movement is programmed and controlled by a computer on hydraulic or mechanical presses (Figure 5) in order to avoid too large differences in the green density of the compact and its uniform ejection out of the die.

In spite of this, it is not possible to ensure that a green compact has a completely uniform green density over the whole volume (Figure 4), especially, if in the product design phase, it is not possible to avoid larger height differences, sharp crossings and chamfers, because of other functional limitations of the final sintered product. ${ }^{5}$ The results of an unsuitable geometry of the product are: non-uniform powder filling of the die, large local compaction pressures, forming large local greendensity differences, and finally cracking of the green compact during ejection. However, these also lead to wear/fracture of the most loaded tool parts and overall shorten the life of the tool. Tools (dies) for the compaction of metal powders are very precise, made of advanced tool steels and cemented carbides, and therefore, their manufacture is very complex and expensive. Tool life depends not only on its complexity but also on powder engineering (technological) properties. Metal powders have to have a large tap density, good flowability and compressibility for the appropriate ADC.

One such sintered steel product that has a difficult ADC geometry is the two-height small gear produced in the Unior factory (Figure 6). It also has a very small gear module $(m=0.5)$ as well as large height and diameter differences.
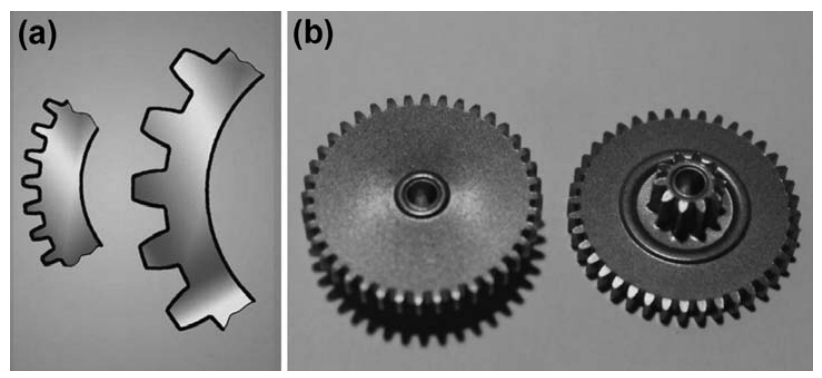

Figure 6: a) Schematic presentation of small and large gear module and b) a photograph of the discussed small complex double spur gear with the dimensions $5 / 40-7 / 10 \times 7 \mathrm{~mm}$, produced in the Sinter Workshop, Unior factory, Zreče, Slovenia

Slika 6: a) Shematični prikaz ozobljenja z majhnim in velikim modulom in b) posnetek obravnavanega majhnega dvojnega sintranega zobnika $5 / 40-7 / 10 \times 7 \mathrm{~mm}$, ki ga izdelujejo v obratu Sinter, Unior, Zreče 


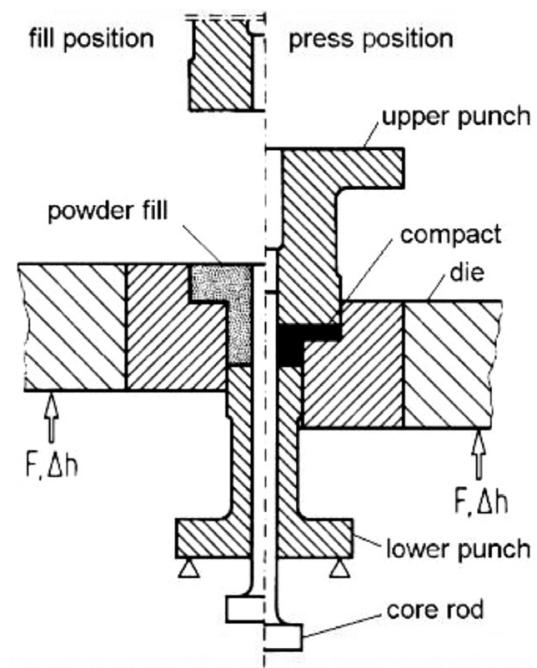

Figure 7: Schematic presentation of the cross-section of the tool for the uniaxial ADC of the double-height product ${ }^{5}$

Slika 7: Shematični prikaz prereza sestave orodja za stiskanje dvovišinskega izdelka ${ }^{5}$

This small gear is compacted with very high compacting pressures in order to decrease the differences in the green density in the gear teeth because of poor filling of the engraving, as well as to decrease the differences in the green density between the gear parts with a large height difference to avoid cracking at the height crossing. This demands high compaction pressures over 700 $\mathrm{MPa}$. The result is a too short tool-life because of frequent fracture of the most loaded tool parts (punches and core rods, Figure 7).

Different solutions (better tool materials, more precise tooling, optimization of the die and press set up) have been researched to solve this problem. But no one has found a complete result and a final solution. Therefore, we also tried with a change of the existing powder granulometry. The hypothesis was that the selection of a finer powder could offer better compressibility and filling of the die. Unfortunately, as it follows, the change of the granulometry to a finer powder also did not give an improvement of the ADC process but gave us a lot of useful and interesting information.

\section{EXPERIMENTAL WORK}

For the production of the investigated two-height gear a standard commercial diffusion prealloyed Fe-based powder Distaloy AB, Höganäs, Sweden was used. Its average nominal bulk chemical composition in mass fractions $(w / \%)$ is: $1.7 \mathrm{Ni}, 1.5 \mathrm{Cu}, 0.5 \mathrm{Mo}$, and the rest is Fe. The addition of carbon (generally $0.4-0.6 \%$ graphite) changes it during the sintering into a steel with the required chemical composition. The $5 \mathrm{~kg}$ of original Distaloy AB powder was sieved on a set of vibrating sieves in the frame of our experimental work. The finest powder fraction $(<45 \mu \mathrm{m})$ was selected for our subsequent experiments and investigations.
The compressibility of the selected fine $(<45 \mu \mathrm{m})$ and rough $(>45 \mu \mathrm{m})$ mixtures was determined by instrumented apparatus ${ }^{6}$ in standardized die dimensions of $\phi$ $24 \mathrm{~mm} \times 16 \mathrm{~mm}$. The experiment for the compressibility determination is performed at a ram speed of 10 $\mathrm{mm} / \mathrm{min}$. It is a much slower speed than the actual industrial ADC process. Therefore, the densification and deformation rate of the green compact in industrial conditions are different and higher (a larger number of structural defects affecting the sintering), respectively. The flowability and tap density of the selected powder mixtures were determined with a Hall flowmeter ${ }^{1}$. The prescribed amount of graphite $(w=0.5 \%)$ and Kenolube lubricant $(w=0.9 \%)$ were added to the original Distaloy $\mathrm{AB}$ and the fine sieved powder and both were then homogenized in a double-cone mixer. The experimental compaction of the gears was performed on an industrial $60 \mathrm{kN}$ Dorst, Germany, mechanical press. Approximately 100 gear pieces were compacted from both powder mixtures followed by the sintering of green compacts in an industrial continuous-belt Mahler furnace under standard sintering conditions $\left(1120{ }^{\circ} \mathrm{C} / 30 \mathrm{~min}\right)$ in a protective atmosphere $\left(\mathrm{N}_{2}+5 / 10 \% \mathrm{H}_{2}\right)$. The sintered gears were additionally heat treated after sintering (oil quench-
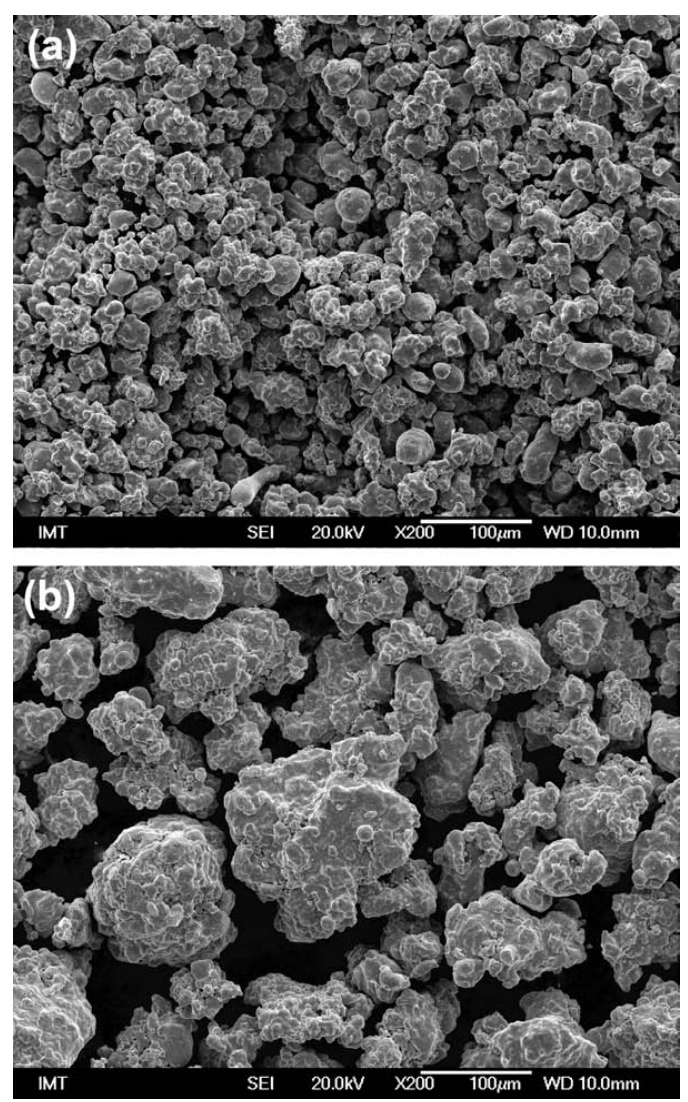

Figure 8: SEM micrograph of: a) fine (sieved $<45 \mu \mathrm{m}$ ) and b) large $(>45 \mu \mathrm{m}$ sieve residual) powder mixture Distaloy $\mathrm{AB}$; magnification 200-times

Slika 8: SEM-posnetka: a) fine (presejane na $<45 \mu \mathrm{m}$ ) in b) grobe (ostanek po sejanju $>45 \mu \mathrm{m}$ ) frakcije kovinskega prahu Distaloy AB; povečava 200-kratna 
ing from $890{ }^{\circ} \mathrm{C}$ and tempering at $200{ }^{\circ} \mathrm{C} / 30 \mathrm{~min}$ ) The Vickers hardness HV5 of the sintered and heat-treated gears and the mechanical moment (teeth strength) were determined. The local bulk and micro-chemical compositions of the powders, green compacts and sintered gears were determined with an SEM/EDS (Jeol JSM6500F/Oxford INCA ENERGY 450, INCA X-SIGHT LN2) and an XRF analyzer (Thermo Scientific, Niton XL3t Goldd+).

\section{RESULTS AND DISCUSSION}

Figure 8 shows scanning electron micrographs of the fine and rough fractions of the investigated powders. The powders do not have large differences in morphology (shape and surface state), with the exception of the particle size. However, micro-chemical SEM/EDS analyses have shown that the local chemical composition of the fine fraction is significantly different compared to the original mixture. The most probable reason is the method of powder alloying. The used Distaloy AB powder is diffusion prealloyed (Figure 9b) and segregation of the alloying elements occurred during sieving and finer powder particles have a different chemical composition than the larger ones. Figure 10 shows EDS micro-chemical mapping analyses of the fine and large powder particles. It is clear that their local compositions are quite different. This was also confirmed by the XRF analyses, which included a much larger volume of analyzed sample. In spite of this, the local chemical compositions of all the samples differ significantly from the nominal chemical composition of the Distaloy AB powder. Table 1 shows the average chemical compositions of all the

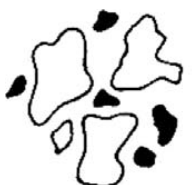

a) $\square$ Base powder

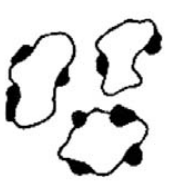

b)

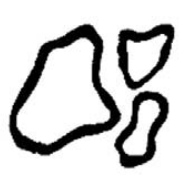

c)

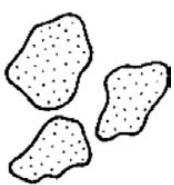

d)
Figure 9: Standard ways of alloying techniques in powder metallurgy ${ }^{5}$ Slika 9: Standardni načini legiranja v metalurgiji prahov ${ }^{5}$

Table 1: Average XRF bulk chemical compositions of analyzed samples in mass fractions, $w / \%$

Tabela 1: Povprečne XRF kemijske sestave analiziranih vzorcev v masnih deležih, $w / \%$

\begin{tabular}{|c|c|c|c|c|c|c|c|c|}
\hline No. & Sample & $\mathrm{Fe}$ & $\mathrm{Ni}$ & $\mathrm{Cu}$ & $\mathrm{Mo}$ & $\mathrm{Mn}$ & $\mathrm{Cr}$ & $\mathrm{Si}$ \\
\hline 1 & Fine powder & 74.14 & 14.38 & 9.99 & 0.84 & 0.09 & 0.05 & 0.13 \\
\hline 2 & $\begin{array}{c}\text { Green compact } \\
\text { fine powder }\end{array}$ & 83.03 & 9.73 & 5.91 & 0.78 & 0.09 & 0.04 & 0.12 \\
\hline 3 & $\begin{array}{c}\text { Sintered gear fine } \\
\text { powder }\end{array}$ & 88.92 & 5.47 & 4.42 & 0.80 & 0.20 & 0.05 & 0.08 \\
\hline 4 & $\begin{array}{c}\text { Green compact } \\
\text { original powder }\end{array}$ & 90.57 & 4.72 & 3.53 & 0.60 & 0.10 & 0.06 & 0.17 \\
\hline 5 & $\begin{array}{c}\text { Sintered compact } \\
\text { original powder }\end{array}$ & 93.65 & 3.10 & 2.11 & 0.65 & 0.13 & 0.06 & 0.12 \\
\hline
\end{tabular}
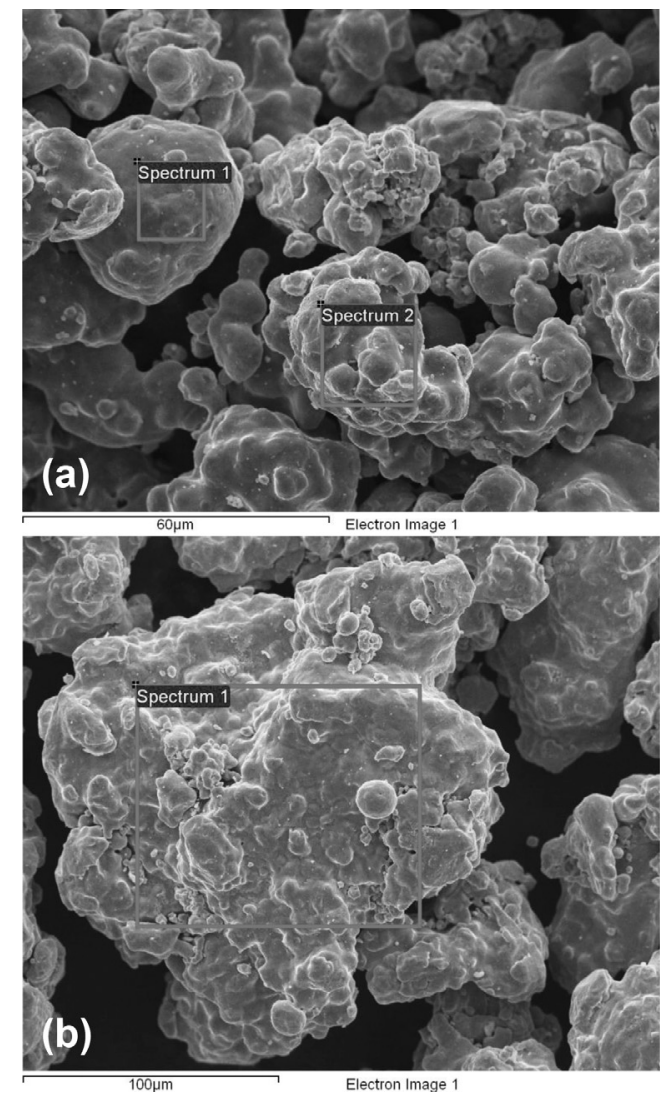

\begin{tabular}{|c|c|c|c|c|}
\hline (a) & $\mathrm{Fe}$ & $\mathrm{Ni}$ & $\mathrm{Cu}$ & $\mathrm{Mo}$ \\
\hline Spectrum 1 & 92.54 & 4.01 & 1.71 & 1.74 \\
\hline Spectrum 2 & 98.96 & 0.41 & 0.63 & 0.00 \\
\hline
\end{tabular}

\begin{tabular}{|c|c|c|c|c|}
\hline (b) & $\mathrm{Fe}$ & $\mathrm{Ni}$ & $\mathrm{Cu}$ & $\mathrm{Mo}$ \\
\hline Spectrum 1 & 97.51 & 0.81 & 0.71 & 0.97 \\
\hline Spectrum 2* & 87.27 & 0.76 & 9.94 & 2.03 \\
\hline
\end{tabular}

* not designated in the micrograph

Figure 10: Mapping SEM/EDS microanalyses of: a) fine and b) large powder particles in mass fractions, $w / \%$

Slika 10: Primer ploskovne SEM/EDS-mikroanalize: a) finega in b) grobega delca $\mathrm{v}$ masnih deležih, $w / \%$

analyzed samples. It is clear that the fine powder mixtures have a much higher content of alloying elements than the original powder mixture. As will be shown later, this over-alloying also has a significant influence on the mechanical properties of the sintered and heat-treated gears.

Table 2 shows the results of the technological properties of the original, fine and rough powder mixture. We can see from this table that the fine fraction mixture has a poorer flowability, a lower tap density $\left(\rho_{\mathrm{n}}\right)$ and a negligibly better compressibility $\left(\rho_{\mathrm{z}}\right.$ at $\left.p_{\mathrm{sr}}\right)$. Our hypothesis was that the finer powder mixture has a better ability to fill the die cavity, but obviously the experiments disprove this.

In this way the original powder mixture has a significantly better flowability, a higher tap density and a negligibly lower compressibility, and is therefore more suitable for ADC. This was also confirmed by our indu- 


\section{B. ŠUŠTARŠIČ et al.: THE INFLUENCE OF THE MORPHOLOGY OF IRON POWDER PARTICLES ...}

Table 2: Technological properties of the steel powder Distaloy AB, Höganäs

Tabela 2: Tehnološke lastnosti kovinskega prahu Distaloy AB, Höganäs

\begin{tabular}{|l|c|c|c|c|c|c|}
\hline \multicolumn{1}{|c|}{ Powder type } & $\rho_{\mathrm{n}} /\left(\mathrm{g} / \mathrm{cm}^{3}\right)$ & $\begin{array}{c}\text { Flowability } \\
s / 50 \mathrm{~g}\end{array}$ & $p_{\max } / \mathrm{MPa}$ & $p_{\mathrm{sr}} / \mathrm{MPa}$ & $\rho_{\mathrm{z}} /\left(\mathrm{g} / \mathrm{cm}^{3}\right)$ & Remarks \\
\hline Original powder & 3.06 & 26 & \multicolumn{2}{|c|}{$7.10 \mathrm{~g} / \mathrm{cm}^{3}$ at $600 \mathrm{MPa}$} & lubricant Kenolube \\
\hline Fine fraction $(<45 \mu \mathrm{m})$ & 2.75 & 30 & 722.6 & 595.4 & 7.15 & \multirow{2}{*}{ lubricant stearic acid } \\
\hline Rough fraction $(>45 \mu \mathrm{m})$ & 2.99 & 26 & 738.5 & 512.4 & 6.94 & \\
\hline
\end{tabular}

* manufacturer's data

strial experiments of the gear compaction. The powder mixture better filled the die cavity and a higher average green density (approx. 7.0-7.1 $\mathrm{g} / \mathrm{cm}^{3}$ ) of the gears at lower compaction pressures (approx. $180 \mathrm{kN}$ ) are obtained. The fine powder mixture did not fill the die cavity so well and a lower average green density (approx. $\left.6.9-7.0 \mathrm{~g} / \mathrm{cm}^{3}\right)$ of the gears at higher compaction pressures (approx. $210 \mathrm{kN}$ ) were obtained. Besides this, the gears made of the fine powder mixture have poorer mechanical properties after sintering and heat-treatment (Table 3). Figures 11 and $\mathbf{1 2}$ show the microstructures of the sintered and heat-treated gears. Figures 11a and 11b show a typical microstructure of a polished sample in the region of the tooth-root of the sintered gear visible under a light microscope (LM). It is clear that the sintered gear made of the original mixture has a larger
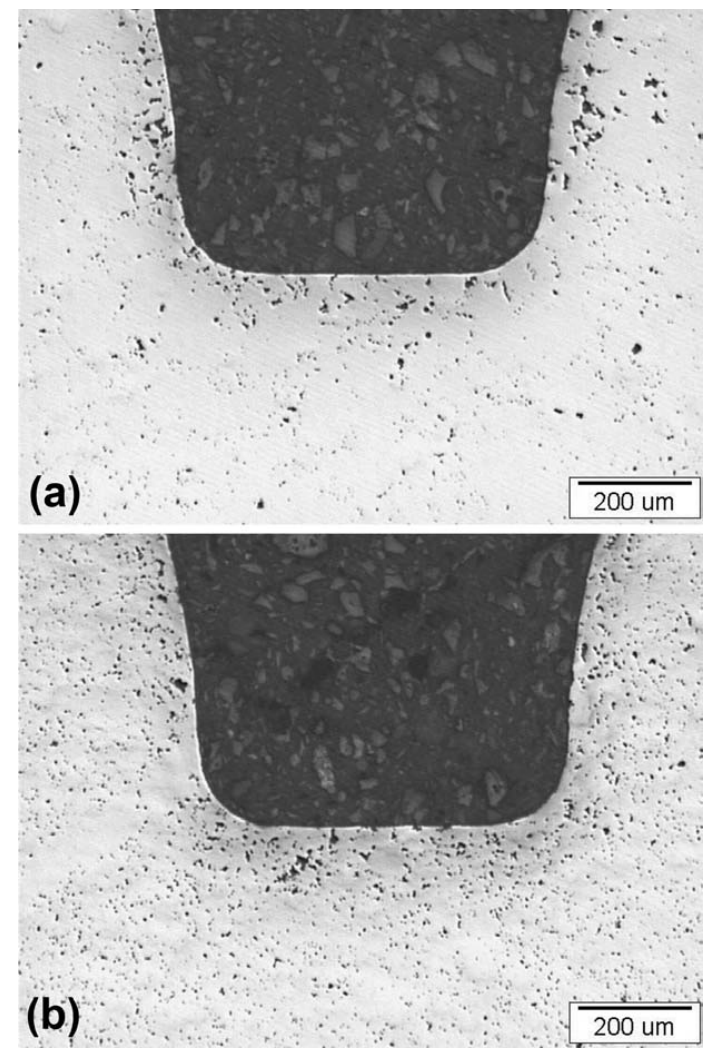

Figure 11: Microstructure of sintered gear: a) produced from original powder mixture and $b$ ) produced from fine sieved powder mixture; polished sample, light microscope; magnification 50-times

Slika 11: Mikrostruktura sintranega zobnika: a) izdelanega iz originalne mešanice in b) iz fine mešanice; poliran vzorec, svetlobni mikroskop; povečava 50-kratna fraction of large pores, but it is better densified in the gear core. This could be a problem of gear resistance to wear and fatigue. On the other hand, the gear made of the finer powder mixture has well-distributed, finer pores, but it is much less densified.

Figures 12a and 12b show typical microstructures of polished and etched samples of the gears after sintering

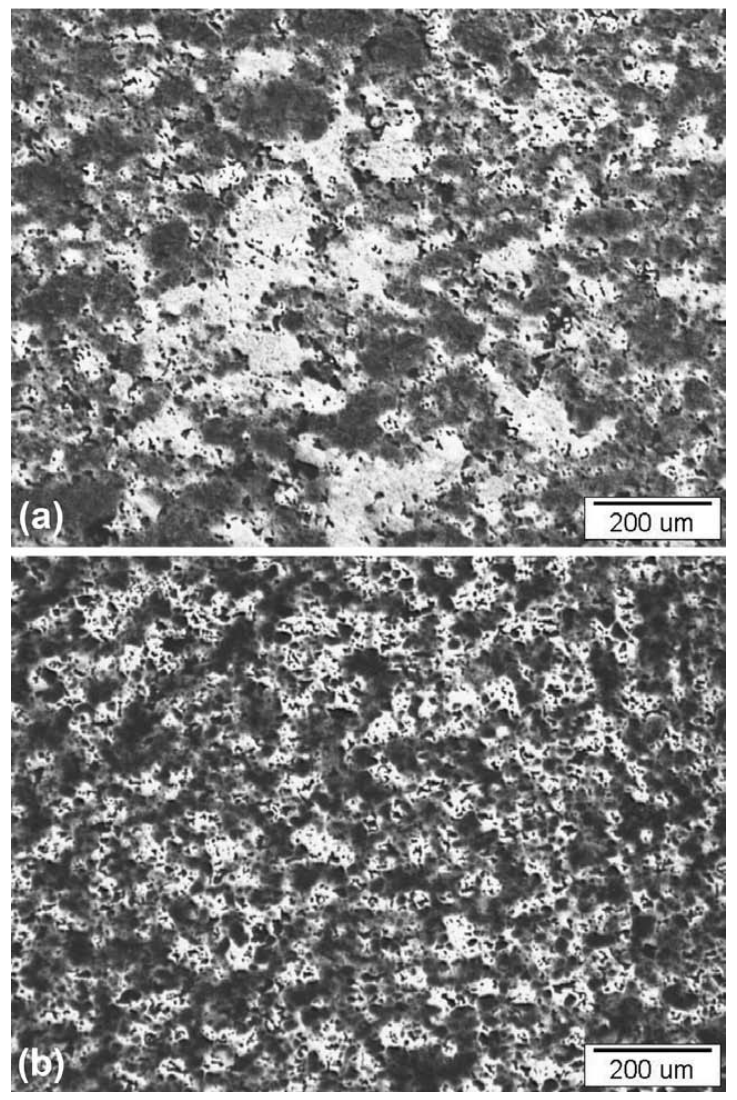

Figure 12: Microstructure of sintered and heat-treated gear: a) produced from original powder mixture and $b$ ) produced from fine sieved powder mixture; polished and nital-etched sample, light microscope, magnification 100-times

Slika 12: Mikrostruktura sintranega in poboljšanega zobnika: a) izdelanega iz originalne mešanice in b) iz fine mešanice; poliran in v nitalu jedkan vzorec, svetlobni mikroskop; povečava 100-kratna

Table 3: Vickers hardness of sintered and tempered gears

Tabela 3: Trdote sintranih in poboljšanih zobničkov

\begin{tabular}{|c|c|c|}
\hline & Original powder & Fine sieved powder \\
\hline Sintered gears & 212 & 298 \\
\hline Tempered gears & 318 & 293 \\
\hline
\end{tabular}


and heat treatment, visible under a LM. The gear made of the original powder mixture has a typical and correct, but heterogeneous, martensitic/bainitic microstructure. However, the gear made of the fine powder mixture has a microstructure in accordance with the inappropriate (over-alloyed) chemical composition.

\section{CONCLUSIONS}

The original prealloyed Fe-based powder Distaloy $\mathrm{AB}$ was sieved and the technological properties of the fine and rough powder fractions important for ADC were determined. The fine powder fraction has a lower tap density, worse flowability and a negligibly better compressibility. It was expected that the selection of the fine powder fraction can contribute to an improvement in the ADC process of a small, two-height gear, especially to better filling of the teeth engraving, as well as a more uniform green-density distribution at a lower compaction pressure. This hypothesis has been disapproved based on experimental and semi-industrial work. It has been found that the selection of the finer powder mixture also has other traps. The sieved finer fraction has a different chemical composition than the original powder mixture. This has an important influence on the sintering and heat-treatment response of the material. Therefore, the poorer mechanical properties of the gears made of the fine fraction were obtained. The open question is also the price of manufacture of the fine powder mixture with the correct chemical composition. For now, the existent ADC procedure for the selected small gears is indicated as optimal. In the future, it will be necessary to find other ways to improve the ADC of small spur gears.

\section{REFERENCES}

${ }^{1}$ R. M. German, Powder Metallurgy Science, Metal Powder Industries Federation (MPIF), Second Edition, Princeton, New Jersey 1994

${ }^{2}$ F. Thümmler, R. Oberacker, Introduction to Powder Metallurgy, The Institute of Materials, The University Press, Cambridge 1993

${ }^{3}$ Powder Metallurgies and Application, ASM Handbook, Volume 7, 1993

${ }^{4}$ Unior, d. d., Forging Industry, Zreče, program Sinter, web page address: http://unior-schmiede.com/cgi-bin/cms.cgi?doc $=20454$

${ }^{5}$ Powder Metallurgy, materials, processes and application, CD product of the European Commission's Leonardo Da Vinci Program, EPMA (European Powder Metallurgy Association), 2000

${ }^{6}$ B. Šuštaršič et al., An instrumented cell to analyse the behaviour of metal powders during cold uniaxial die compaction, Mater. Tehnol., 35 (2001) 6, 351-360 